\title{
BEHAVIOR OF Trichogramma atopovirilia OATMAN \& PLATNER AND T. pretiosum RILEY (HYMENOPTERA: TRICHOGRAMMATIDAE) ON Spodoptera frugiperda (J. E. SMITH) (LEPIDOPTERA: NOCTUIDAE) EGG MASSES
}

\author{
BESERRA, E. B., ${ }^{1}$ DIAS, C. T. ${ }^{2}$ and PARRA, J. R. P. ${ }^{3}$ \\ ${ }^{1}$ Departamento de Famácia e Biologia, Universidade Estadual da Paraíba, C.P. 781/791, \\ CEP 58100-000, Campina Grande, PB, Brazil \\ ${ }^{2}$ Departamento de Ciências Exatas, ESALQ-USP, C.P. 09, CEP 13418-900, Piracicaba, SP, Brazil \\ ${ }^{3}$ Departamento de Entomol., Fitop. e Zool. Agrícola, ESALQ-USP, C.P. 09, \\ CEP 13418-900, Piracicaba, SP, Brazil \\ Correspondence to: José R. P. Parra, Departamento de Ent., Fitop. e Zool. Agrícola, ESALQ/USP, C.P. 09, \\ CEP 13418-900, Piracicaba, SP, Brazil, e-mail: jrpparra@esalq.usp.br \\ Received June 6, 2003 - Accepted July 16, 2003 - Distributed February 28, 2005
}

(With 2 figures)

\begin{abstract}
In this study we analyzed the impact of physical barriers of Spodoptera frugiperda (J. E. Smith) eggmasses on the behavior of Trichogramma atopovirilia Oatman \& Platner and Trichogramma pretiosum Riley. The duration of drumming, drilling, oviposition, period spent over the egg-mass, and interval between parasitized eggs were timed, and the number of parasitized eggs were recorded. The presence of scales on the egg-masses caused a significant increase in the time spent by both parasitoids on each process and a decrease in the residence time over the egg-mass and in the number of parasitized eggs, with an increase in the number of egg layers. There was a significant decrease in the number of parasitized eggs in relation to egg-masses with one layer and no scales. We observed that the physical barriers in fall armyworm egg-masses changed the behavior of T. atopovirilia and T. pretiosum, affecting their parasitization capacity.
\end{abstract}

Key words: egg parasitoid, fall armyworm, parasitization, mechanical defense.

\section{RESUMO}

\section{Comportamento de Trichogramma atopovirilia Oatman \& Platner e T. pretiosum Riley (Hymenoptera: Trichogrammatidae) em posturas de Spodoptera frugiperda (J. E. Smith) (Lepidoptera: Noctuidae)}

O trabalho teve por objetivo avaliar o impacto da barreira física presente nas posturas de Spodoptera frugiperda (J. E. Smith) sobre o comportamento de Trichogramma atopovirilia Oatman \& Platner e Trichogramma pretiosum Riley. Foram avaliados: duração do período de reconhecimento externo do ovo, penetração do ovipositor, oviposição, tempo de permanência sobre a postura, deslocamento da fêmea entre ovos parasitados e número de ovos parasitados. A presença de escamas sobre as posturas aumentou significativamente o tempo gasto em cada etapa do comportamento para ambos os parasitóides e diminuiu o tempo de permanência da fêmea sobre a postura. $\mathrm{O}$ aumento no número de camadas de ovos sobre a postura diminuiu significativamente o número de ovos parasitados em relação a posturas com uma camada de ovos e sem escamas. Foi observado que as barreiras físicas sobre as posturas de S. frugiperda alteraram o comportamento de T. atopovirilia e T. pretiosum, afetando sua capacidade de parasitismo.

Palavras-chave: parasitóide de ovos, lagarta-do-cartucho, parasitismo, defesa mecânica. 


\section{INTRODUCTION}

The use of egg parasitoids of the genus Trichogramma such as Trichogramma atopovirilia Oatman \& Platner and Trichogramma pretiosum Riley (Hym.: Trichogrammatidae) to control corn pests has been investigated by several researchers (Toonders \& Sánchez, 1987; Neil \& Specht, 1990; Sá \& Parra, 1994; Zucchi et al., 1991; Zucchi \& Monteiro, 1997). However, the efficiency of these natural enemies to control Spodoptera frugiperda (J. E. Smith) has been reduced because of the latter's egg-laying features, which includes overlapped layers of eggs covered by scales (Toonders \& Sánchez, 1987). Among the challenges presently facing biological control experts, this is one.

Parasitism behavior is an important indicator of parasitoid performance and successful reproduction (Nurindah et al., 1997). An understanding of the mechanisms and factors involved that interfere with the behavior of a natural enemy can be used to identify the situations in which the release of the parasitoid will impact the pest population. It can also suggest ways of handling the environment so as to increase the efficiency of a given natural outdoors enemy (Thompson \& Stinner, 1990).

Trichogramma behavior is usually mediated by chemical (kairomones) (Noldus, 1989) and physical (volume, shape, and texture) stimuli from the host (Schmidt \& Smith, 1985). Nevertheless, for a host such as $S$. frugiperda, another factor to be included among characteristics of insect parasitism behavior is the arrangement of the eggs in layers as well as the scales found on the eggs, which can alter parasitism behavior and affect control efficiency possible through the use of Trichogramma. The effect of these factors on parasitism behavior can be measured by timing the insect as it finds and parasitizes a host egg. Depending on the host species and related chemical and physical characteristics, and on the physiological condition of a given wasp, the time spent in these behaviors can change (Schmidt \& Smith, 1985; Pak et al., 1986; De-Cheng et al., 1988).

The difficulty of Trichogramma in parasitizing $S$. frugiperda egg masses has been reported by several researchers (Toonders \& Sánchez, 1987; Sifontes et al., 1988; Armas \& Ayala, 1993) but most of these studies are restricted to parasitism capacity without considering the effects on parasitoid behavior due to the presence of physical barriers on $S$. frugiperda egg masses. Thus, an analysis under laboratory conditions of behavior, which takes into account these barriers, is required to better understand the parasitoid-host relationship as well as implications for a biological control program targeting $S$. frugiperda and using these egg parasitoids. The goal of this research is to evaluate both the effect of egg distribution in layers and the presence of scales on $S$. frugiperda eggs on oviposition behavior of $T$. atopovirilia and T. pretiosum.

\section{MATERIAL AND METHODS}

The research was carried out at the Insect Biology Laboratory, Department of Entomology, Plant Pathology, and Agricultural Zoology, ESALQ/ USP, Piracicaba, SP, Brazil. T. pretiosum originated in $S$. frugiperda-parasitized eggs collected in corn plantations in the region of Piracicaba, SP, Brazil. T. atopovirilia was obtained from the Centro de Pesquisa Agropecuária do Trópico Semi-Árido (CPATSA), of the Empresa Brasileira de Pesquisa Agropecuária (EMBRAPA), Petrolina, PE, Brazil. Laboratory rearing was conducted in glass tubes $(8.5 \times 2.5 \mathrm{~cm})$, with Anagasta kuehniella (Zeller) (Lep., Pyralidae) eggs supplied as factitious host following the methodology of Parra et al. (1989) and Parra (1997). The temperature, relative, humidity, and photoperiod conditions were, respectively, $25^{\circ} \mathrm{C} \pm 2{ }^{\circ} \mathrm{C}, 70 \% \pm 10 \%$, and $14 \mathrm{~L}: 10 \mathrm{D}$.

The parasitism behavior of $T$. atopovirilia and T. pretiosum was individually evaluated based on different physical characteristics and using newly laid eggs (0-12 hours) of $S$. frugiperda. The treatments follow: 1 . one layer of eggs with no scales; 2. two layers of eggs with no scales; 3 . one layer of eggs with low scale density; 4 . one layer of eggs with high scale density. For each type of eggs laid, 20-30 T. atopovirilia or T. pretiosum females of up to 24 hours of age, fed on pure bee honey, and without previous oviposition experience, were individualized in glass tubes $(12.0 \times 7.0 \mathrm{~mm})$. They were filmed for $20 \mathrm{~min}$ under a stereoscopic microscope (Leica-Wild M10) coupled to a video camera (VK-C360N, Hotachi®) adapted to a video system. Evaluations, which began after the parasitoid met the host egg, determined the duration of: 1. drumming (period in which the female steps on the egg surface and touches it with her antenna); 2. drilling (characterized by a vertical downward 
and upward motion of the abdomen during which the female introduces the ovipositor and performs an internal examination of the host egg); 3 . oviposition (this parameter was quantified together with the egg-marking time); 4 . total time on each egg; 5. female residence parasitizing on the eggs laid; 6 . female movement among parasitized eggs (between the end of an oviposition and beginning of the next drumming); and 7. number of parasitized eggs.

The parameters evaluated during oviposition behavior were submitted to analysis of variance, and significance difference was tested according to Fisher's protected least significant difference (PLSD) test $(\mathrm{p} \leq 0.05)$. The treatments were arranged in a factorial scheme with two factors with interactions: the Trichogramma species and type of eggs laid, in a completely randomized block design. A correlation analysis was performed to determine possible relationships between the time during which the female remained parasitizing the eggs and the number of eggs parasitized, and between the number of eggs parasitized and the time elapsed from the end of an egg parasitism to the beginning of the following drumming. This was carried out through SAS software (1998).

\section{RESULTS}

Considering only the females that parasitized the host eggs, the time spent by Trichogramma spp. in each of the parasitism behavior steps of proved to vary according to the physical barriers in the S. frugiperda egg mass. For both Trichogramma species studied, the time in each of these steps increased and the number of parasitized eggs decreased significantly with the presence of scales on the eggs (Tables 1 and 2). On scaly eggs, the females had difficulty walking over the eggs and finding a position, which contributed to the increase in time spent especially for drilling and, accordingly, in total time spent on each parasitized egg (Table 1).

More drastic effects of scale presence on $S$. frugiperda eggs were observed in the behavior of T. pretiosum. In eggs with no scales (layers 1 and 2 ) and eggs with low scale density, $100 \%$ of the females parasitized the host. On the other hand, the $T$. pretiosum females had more difficulty in parasitizing high scale-density eggs, and only $60 \%$ were able to parasitize, while $100 \%$ of $T$. atopovirilia females could.

Significant interactions of the species ( $T$. atopovirilia and T. pretiosum) and treatment (egglaying type) factors were observed only for the duration of the drilling period of the ovipositor $(\mathrm{F}=10.6 ; \mathrm{p}=0.0001)$, total time on each parasitized egg $(F=2.7 ; p=0.04)$, and number of parasitized eggs $(\mathrm{F}=4.8 ; \mathrm{p}=0.009)$ (Table 1$)$. These results show that $T$. atopovirilia and $T$. pretiosum present differences in relation to each of these three behavioral steps and that for each species, the time in each step of the behavior and the number of parasitized eggs are modified according to the physical barriers of $S$. frugiperda egg laying. Overall, T. atopovirilia required a larger period of time to examine and parasitize the host egg than did $T$. pretiosum (Table 1).

The time spent by a female parasitizing the eggs was positively correlated with the number of parasitized eggs, both for $T$. atopovirilia $(\mathrm{t}=5.8$; $\mathrm{p}=0.00008 ; \mathrm{r}=0.56)$ and $T$. pretiosum $(\mathrm{t}=15.5$; $\mathrm{p}=0.00001 ; \mathrm{r}=0.85)$ (Fig. 1) and these parameters were significantly lower on scaly eggs (Table 2 ). No significant interaction was observed regarding the time spent by females parasitizing the egg between the species (T. atopovirilia and $T$. pretiosum) and treatment (type of eggs laid) $(\mathrm{F}=$ $1.5 ; \mathrm{p}=0.23$ ). However, a significant difference occurred between the species $(\mathrm{F}=8.39 ; \mathrm{p}=0.0004)$ and among treatments $(\mathrm{F}=7.45 ; \mathrm{p}=0.0009)$. Overall, T. atopovirilia spent a greater period of time parasitizing the eggs than was the case for $T$. pretiosum, although with respect to the number of parasitized eggs a significant difference between species was only observed for eggs with one layer and no scales, and eggs with high scale density. In the latter case, T. atopovirilia had a higher parasitism capacity than $T$. pretiosum (Table 2 ). These results show that the type of eggs has an effect on the time that females spend parasitizing and, therefore, interferes with their parasitism capacity. In addition, the period from the end of parasitizing one egg to beginning the next drumming was longer for scaly eggs.

Scaly eggs were also less parasitized by Trichogramma spp. which can be explained by the difficulty the females have in examining and ovipositing on the host egg, and by the time spent by the insect to move on the eggs, as shown in the 
correlation analysis, with an inverse relationship between the increase of time elapsed between the parasitized eggs and the number of eggs parasitized by $T$. atopovirilia $(\mathrm{t}=8.5 ; \mathrm{p}=0.00001 ; \mathrm{r}=0.70)$ and $T$. pretiosum $(\mathrm{t}=9.9 ; \mathrm{p}=0.00001 ; \mathrm{r}=0.75)$ (Fig. 2).

TABLE 1

Duration (s) of the parasitism behavior steps of $T$. atopovirilia and $T$. pretiosum in $S$. frugiperda eggs with different physical characteristics. Time of observation: 20 minutes.

\begin{tabular}{|c|c|c|}
\hline \multirow{3}{*}{ Treatment } & \multicolumn{2}{|c|}{ Behavioral step } \\
\hline & \multicolumn{2}{|c|}{ Drumming $^{1}$} \\
\hline & T. atopovirilia & T. pretiosum \\
\hline \multirow{7}{*}{$\begin{array}{l}\text { One layer with no scales } \\
\text { Two layers with no scales } \\
\text { One layer with low scale density } \\
\text { One layer with high scale density } \\
\text { Overall average }\end{array}$} & $23.9 \pm 1.3 \mathrm{~A}^{3}(\mathrm{n}=20)$ & $15.9 \pm 0.7$ A $(n=20)$ \\
\hline & $29.1 \pm 1.2 \mathrm{AB}^{3}(\mathrm{n}=20)$ & $20.1 \pm 1.2 B(\mathrm{n}=20)$ \\
\hline & $30.4 \pm 2.0$ B $(\mathrm{n}=20)$ & $21.7 \pm 1.3 B(n=19)$ \\
\hline & $31.2+2.4 B(\mathrm{n}=18)$ & $23.9 \pm 1.5 B(n=18)$ \\
\hline & $28.6 \pm 0.9 \mathrm{a}$ & $20.4 \pm 0.7 \mathrm{~b}$ \\
\hline & \multicolumn{2}{|c|}{ Drilling } \\
\hline & T. atopovirilia & T. pretiosum \\
\hline \multirow{7}{*}{$\begin{array}{l}\text { One layer with no scales } \\
\text { Two layers with no scales } \\
\text { One layer with low scale density } \\
\text { One layer with high scale density } \\
\text { Overall average }\end{array}$} & $44.7 \pm 3.5 \mathrm{bA}^{3}(\mathrm{n}=20)$ & $23.2 \pm 0.6$ aA $(n=20)$ \\
\hline & $38.2 \pm 1.9$ bA $(\mathrm{n}=20)$ & $32.3 \pm 2.5 \mathrm{aB}(\mathrm{n}=20)$ \\
\hline & $53.2 \pm 7.0 \mathrm{bB}(\mathrm{n}=20)$ & $39.7 \pm 2.1 \mathrm{aC}(\mathrm{n}=19)$ \\
\hline & $73.0 \pm 5.5 \mathrm{bC}(\mathrm{n}=18)$ & $41.1 \pm 2.1 \mathrm{aC}(\mathrm{n}=18)$ \\
\hline & $52.3 \pm 2.8 \mathrm{a}$ & $34.1 \pm 1.3 \mathrm{~b}$ \\
\hline & \multicolumn{2}{|c|}{ Oviposition } \\
\hline & T. atopovirilia & T. pretiosum \\
\hline \multirow{7}{*}{$\begin{array}{l}\text { One layer with no scales } \\
\text { Two layers with no scales } \\
\text { One layer with low scale density } \\
\text { One layer with high scale density } \\
\text { Overall average }\end{array}$} & $43.9 \pm 4.2 A^{3}(n=20)$ & $38.3 \pm 2.5$ A $(n=20)$ \\
\hline & $41.5 \pm 3.6$ A $(n=20)$ & $54.8 \pm 6.4$ AB $(n=20)$ \\
\hline & $62.6 \pm 14.0 \mathrm{~A}(\mathrm{n}=20)$ & $54.7 \pm 7.8 \mathrm{AB}(\mathrm{n}=19)$ \\
\hline & $53.0 \pm 7.6$ A $(\mathrm{n}=18)$ & $62.1 \pm 4.9 B(\mathrm{n}=18)$ \\
\hline & & $52.5 \pm 3.1 \mathrm{a}$ \\
\hline & \multicolumn{2}{|c|}{ Mean total time on each parasitized egg $^{2}$} \\
\hline & T. atopovirilia & T. pretiosum \\
\hline One layer with no scales & $125.8 \pm 8.2 \mathrm{bA}^{3}(\mathrm{n}=20)$ & $87.2 \pm 2.8$ aA $(n=20)$ \\
\hline Two layers with no scales & $123.6 \pm 6.0 \mathrm{aA}(\mathrm{n}=20)$ & $118.6 \pm 9.7 \mathrm{aB}(\mathrm{n}=20)$ \\
\hline One layer with low scale density & $160.2 \pm 19.5$ aAB $(n=20)$ & $128.3 \pm 9.3$ aBC $(n=19)$ \\
\hline One layer with high scale density & $171.7 \pm 12.3 \mathrm{aB}(\mathrm{n}=18)$ & $139.8 \pm 7.2 \mathrm{aC}(\mathrm{n}=18)$ \\
\hline Overall average & $145.3 \pm 12.1 \mathrm{~b}$ & $118.5 \pm 7.3 \mathrm{a}$ \\
\hline
\end{tabular}

${ }^{1,2}$ Data transformed into $\log \mathrm{x}$ and $\mathrm{x}^{-1}$, respectively.

${ }^{3}$ Means followed by the same lower-case letter in rows and capital letter in columns do not differ by the PLSD test ( $p<$ $0.05)$. 
TABLE 2

Time spent by females of $T$. atopovirilia and $T$. pretiosum on $S$. frugiperda eggs, time elapsed among parasitized eggs, and knumber of eggs parasitized together with their different physical characteristics. Time of observation: 20 min.

\begin{tabular}{|c|c|c|}
\hline \multirow{3}{*}{ Treatment } & \multicolumn{2}{|c|}{ Behavioral step } \\
\hline & \multicolumn{2}{|c|}{ Time spent by the female on the eggs ${ }^{1}$} \\
\hline & T. atopovirilia & T. pretiosum \\
\hline \multirow{7}{*}{$\begin{array}{l}\text { One layer with no scales } \\
\text { Two layers with no scales } \\
\text { One layer with low scale density } \\
\text { One layer with high scale density } \\
\text { Overall average }\end{array}$} & $1168.5 \pm 11.8 \mathrm{~A}^{3}(\mathrm{n}=20)$ & $1151.8 \pm 11.1 \mathrm{~A}(\mathrm{n}=20)$ \\
\hline & $1187.3 \pm 6.7$ A $(n=20)$ & $1142.1 \pm 8.5$ A $(n=20)$ \\
\hline & $1136.8 \pm 15.0$ A $(n=20)$ & $1050.4 \pm 15.0$ B $(n=19)$ \\
\hline & $1028.3 \pm 48.6$ B $(\mathrm{n}=18)$ & $746.1 \pm 76.3 \mathrm{C}(\mathrm{n}=30)$ \\
\hline & $1130.2 \pm 47.9 \mathrm{a}$ & $1022.6 \pm 31.6 \mathrm{~b}$ \\
\hline & \multicolumn{2}{|c|}{ Gap among parasitized eggs ${ }^{2}$} \\
\hline & T. atopovirilia & T. pretiosum \\
\hline \multirow{7}{*}{$\begin{array}{l}\text { One layer with no scales } \\
\text { Two layers with no scales } \\
\text { One layer with low scale density } \\
\text { One layer with high scale density } \\
\text { Overall average }\end{array}$} & $9.7 \pm 1.5 \mathrm{~A}^{3}(\mathrm{n}=20)$ & $13.3 \pm 2.3 \mathrm{~A}(\mathrm{n}=20)$ \\
\hline & $8.4 \pm 0.9$ A $(n=20)$ & $15.6 \pm 2.0 \mathrm{~A}(\mathrm{n}=20)$ \\
\hline & $32.5 \pm 4.7$ B $(n=20)$ & $46.8 \pm 5.5$ B $(n=19)$ \\
\hline & $94.2 \pm 23.4 \mathrm{C}(\mathrm{n}=18)$ & $128.1 \pm 31.3 C(n=18)$ \\
\hline & $36.26 .6 \mathrm{a}$ & $51.0 \pm 9.0 \mathrm{~b}$ \\
\hline & \multicolumn{2}{|c|}{ Number of parasitized eggs } \\
\hline & T. atopovirilia & T. pretiosum \\
\hline One layer with no scales & $7.9 \pm 0.5 \mathrm{bA}^{3}(\mathrm{n}=20)$ & $9.5 \pm 0.4$ aA $(n=20)$ \\
\hline Two layers with no scales & $8.2 \pm 0.4$ aA $(\mathrm{n}=20)$ & $7.0 \pm 0.5 \mathrm{aB}(\mathrm{n}=20)$ \\
\hline One layer with low scale density & $5.6 \pm 0.4 \mathrm{aB}(\mathrm{n}=20)$ & $4.8 \pm 0.4 \mathrm{aC}(\mathrm{n}=19)$ \\
\hline One layer with high scale density & $4.1 \pm 0.5 \mathrm{aC}(\mathrm{n}=18)$ & $2.2 \pm 0.4 \mathrm{bD}(\mathrm{n}=30)$ \\
\hline Overall average & $6.4 \pm 0.3 \mathrm{a}$ & $5.9 \pm 0.3 \mathrm{a}$ \\
\hline
\end{tabular}

\section{DISCUSSION}

Trichogramma females use physical (shape, texture, size, etc.) (Schmidt \& Smith, 1985) and chemical stimuli (kairomones) (Noldus, 1989) as signs to recognize and parasitize a host egg. The scales found on Lepidoptera eggs are identified as a chemical stimulus that attracts parasitoids of this genus. However, in S. frugiperda eggs, these scales accounted for the time increase in each step of the parasitism behavior and for the decreased number of eggs parasitized by T. atopovirilia and T. pretiosum.

Regardless of the changes observed in the parasitism behavior as a consequence of scales on the eggs, T. atopovirilia and T. pretiosum showed differences in relation to their behavioral pattern. Overall, T. atopovirilia required more time to recognize and parasitize the host egg than $\operatorname{did} T$. pretiosum. On the other hand, the values observed or the time spent in each step of the behavior of $T$. atopovirilia and T. pretiosum were lower than those observed by Suzuki et al. (1984), Pak et al. (1990), and Nurindah et al. (1999) for Trichogramma chilonis Ishii on eggs of Papilio xuthus L. (Lep., Papilionidae); T. maidis, T. brassicae Voegelé, and T. evanescens Westwood on eggs of Mamestra brassicae L., Pieris brassicae L., and Pieris rapae L. (Lep., Pieridae); and for T. australicum Girault on eggs of Helicoverpa armigera (Hübner) (Lep., Noctuidae). In this case, in addition to the different behavioral patterns, other dissimilarities observed can be attributed to the host egg type. In the species studied by Suzuki et al. (1894), Pak et al. (1990), and Nurindah et al. (1999), the parasitoids were offered isolated eggs with no scales, 
whereas in this study, S. frugiperda eggs were supplied in groups, with less distance between one another, a lesser superficial area and, apparently, lesser host volume, which according to Schmidt \& Smith (1985), accounts for the decreased evaluation time of an egg parasitized by Trichogramma spp.

According to Schmidt \& Smith (1985), Trichogramma females estimate the total egg volume based on the superficial area exposed in order to define the progeny to be deposited, and a relationship exists between exposed surface area, time of evaluation, and number of offspring laid per host egg. Thus, in egg-mass laying insects such as $S$. frugiperda, that which is laid appears to have less volume and area surface due to contact with neighboring eggs, which contributes to a decrease in the time of evaluation and oviposition and, consequently, in the number of individuals laid per host egg.
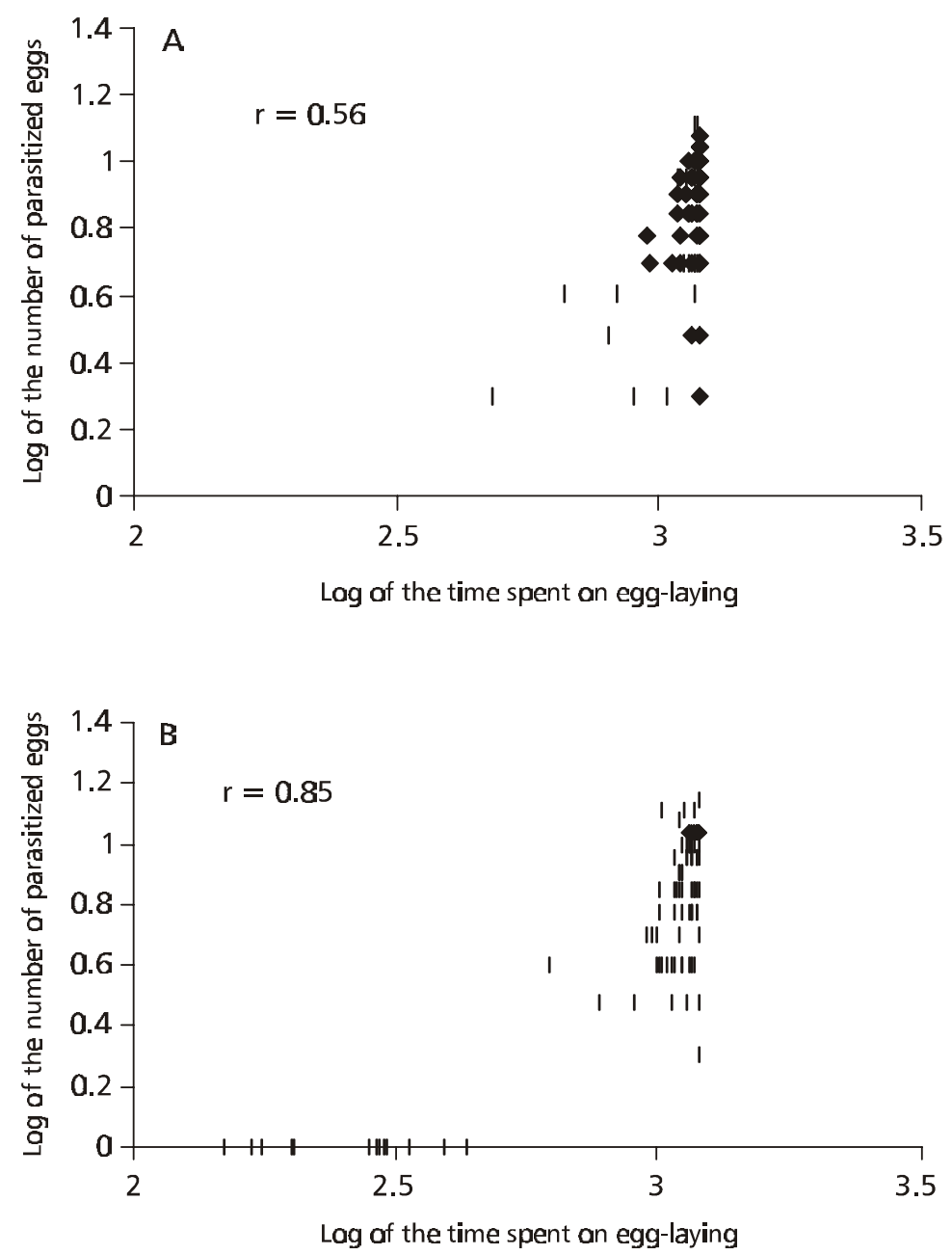

Fig. 1 - Correlation between time spent by the parasitoid female on S. frugiperda eggs and number of parasitized eggs. Time of observation: $20 \mathrm{~min}$. (A) T. atopovirilia; (B) T. pretiosum. 

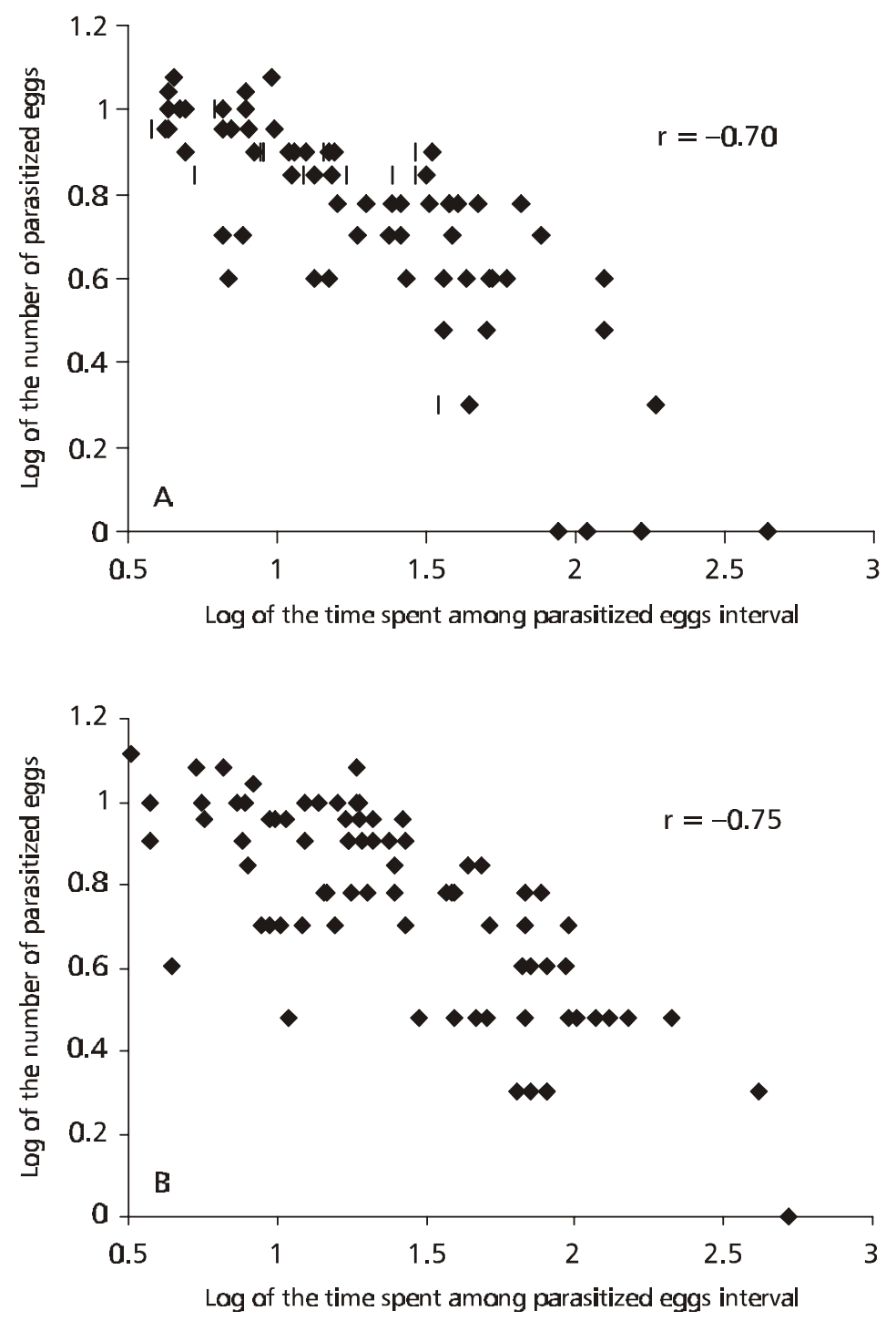

Fig. 2 - Correlation between time elapsed among parasitized eggs and the number of S. frugiperda eggs parasitized. Time of observation: 20 min. (A) T. atopovirilia; (B) T. pretiosum.

In addition to the volume, features such as chorion thickness and hardness are factors that can affect the behavior of a Trichogramma female (Schmidt, 1994). Nevertheless, these features do not seem to interfere with parasitism by $T$. atopovirilia and $T$. pretiosum in $S$. frugiperda eggs, since scale absence resulted in their acceptance by $100 \%$ of the females tested, confirming that these structures work as barriers to parasitism by Trichogramma spp.

The females had more difficulty in parasitizing high scale-density eggs, and the number of parasitized eggs was greatly reduced by both T. atopovirilia and T. pretiosum. In many cases the difficulty imposed by the scale barrier immediately prevented the female from drumming and 
parasitizing the first egg found, often leading the female to move away from the eggs and failing to parasitize or, when parasitizing, doing so only in the few eggs available at the edge of the mass. This decreased the time in which the female parasitized. So, under field conditions, an unsuccessful parasitism experience on high scale-density eggs, in which the insect is not able to parasitize immediately, leads the female to move in her search for new eggs, thereby decreasing her parasitism capacity. Similar observations were made by Garnier-Geoffroy et al. (1996) for T. brassicae that left an area with Ostrinia nubilalis (Hübner) (Lep., Pyralidae) eggs, which they had been unable to contact or parasitize immediately. In addition, Berti \& Marcano (1991) verified that a longer time of absence of host eggs increased egg reabsorption by $T$. pretiosum and decreased parasitism in $S$. cerealella eggs. These discussions show the need of the females to find and parasitize host eggs within a given period of time in order to efficiently control a particular pest.

Parasitoids like Trichogramma show a behavioral pattern involving from locating a susceptible host to its recognition and acceptance (Vinson, 1998). The efficiency with which each step is performed indicates the degree of parasitism success (Hezewijk et al., 2000). In this study, egg distribution in layers and scale presence changed oviposition behavior and the parasitism efficiency of T. atopovirilia and $T$. pretiosum. Although these results cannot be used to measure parasitoid efficiency in the field, they indicate behavior to be expected in a release program for $S$. frugiperda control. Under field conditions, factors like interactions with other biotic components (intraand interspecific interactions) (Bleicher \& Parra, 1989) and climatic conditions (Bourchier \& Smith, 1996) can interfere in the performance of the parasitoids T. atopovirilia and T. pretiosum.

Acknowledgements - We thank CAPES/PICDT for a scholarship grant that made this research possible, and Dr. Francisca Nemaura P. Haji, CPTSA/EMBRAPA, Petrolina, PE, for supplying the initial colony of Trichogramma atopovirilia.

\section{REFERENCES}

ARMAS, J. L. \& AYALA, J. L., 1993, Parasitic behavior, biology, reproduction, and field utilization of Telenomus sp. a native parasitoid of Spodoptera frugiperda in Cuba. Trich. News, 7: 24 .
BERTI, J. \& MARCANO, R., 1991, Efecto del tiempo de ausencia del hospedero sobre el parasitismo por Trichogramma pretiosum Riley (Hymenoptera: Trichogrammatidae). Bol. Entomol. Ven., 6: 5-10.

BLEICHER, E. \& PARRA, J. R. P., 1989, Espécies de Trichogramma parasitóides de Alabama argillacea. I. Biologia de três populações. Pesq. Agrop. Bras., 24: 929-940.

BOURCHIER, R. S. \& SMITH, S. M., 1996, Influence of environmental conditions and parasitoid quality on field performance of Trichogramma minutum. Entomol. Exp. Appl., 80: 461-468.

De-CHENG, D., HONG-QUI, Q. \& JIA-WEL, D., 1988, Host recognition and host acceptance behaviour of Tetrastichus schoenobii. Les Colloques de I'INRA, 43: 173-180.

GARNIER-GEOFFROY, F., ROBERT, P., HAWLITZKY, N. \& FREROT, B., 1996, Oviposition behavior in Ostrinia nubilalis (Lep.: Pyralidae) and consequences on host locations and oviposition in Trichogramma brassicae (Hy.: Trichogrammatidae). Entomophaga, 41: 287-299.

HEZEWIJK, B. H. van, BOURCHIER, R. S. \& SMITH, S. M., 2000, Searching speed of Trichogramma minutum and its potential as a measure of parasitoid quality. Biol. Cont., 17: 139-146.

NEIL, K. A. \& SPECHT, H. B., 1990, Field releases of Trichogramma pretiosum Riley (Hymenoptera: Trichogrammatidae) for suppression of corn earworm, Heliothis zea (Boddie) (Lepidoptera: Noctuidae), egg populations on sweet corn in Nova Scotia. Can. Entomol., 122: 1259-1266.

NOLDUS, L. P. J. J., 1989, Semiochemicals, foraging behaviour and quality of entomophagous insects for biological control. J. Appl. Entomol., 108: 425-451.

NURINDAH, CRIBB, B. W. \& GORDH, G., 1999, Experience acquisition by Trichogramma australicum Girault (Hyemnoptera: Trichogrammatidae). Aus. J. Entomol., 38: 115-119.

NURINDAH, GORDH, G. \& CRIBB, B. W., 1997, Oviposition behaviour and reproductive performance of Trichogramma australicum Girault (Hymenoptera: Trichogrammatidae) reared in artificial diet. Aus. J. Entomol., 36: 87-93.

PAK, G. A., BUIS, H. C. E. M., HECH, I. C. C. \& HERMANS, M. L. G., 1986, Behavioural variations among strains of Trichogramma spp.: host-age selection. Entomol. Exp. Appl., 40: 247-258

PAK, G. A., KASKENS, J. W. M. \& JONG, E. J., 1990, Behavioural variation among strains of Trichogramma spp.: host-species selection. Entomol. Exp. Appl., 56: 91-102.

PARRA, J. R. P., 1997, Técnicas de criação de Anagasta kuehniella, hospedeiro alternativo para produção de Trichogramma. pp. 121-150. In: J. R. P. Parra \& R. A. Zucchi (eds.), Trichogramma e o controle biológico aplicado. FEALQ, Piracicaba, 324p.

PARRA, J. R. P., LOPES, J. R. S., BIRAL, E. \& GOUVEIA, P. C. R., 1989, Número ideal de ovos de Anagasta kuehniella (Zeller, 1879) por caixa de criação para pesquisas com Trichogramma spp. An. Soc. Entomol. Brasil., 18: 391-402. 
SÁ, L. A. N. \& PARRA, J. R. P., 1994, Biology and parasitism of Trichogramma pretiosum Riley (Hym., Trichogrammatidae) on Ephestia kuehniella (Zeller) (Lep., Pyralidae) and Heliothis zea (Boddie) (Lep., Noctuidae) eggs. J. Appl. Entomol., 118: 38-43.

SCHMIDT, J. M. \& SMITH, J. J., 1985, The mechanism by which the parasitoid wasp Trichogramma minutum responds to host clusters. Entomol. Exp. Appl., 39: 287-294.

SCHMIDT, J. M., 1994, Host recognition and acceptance by Trichogramma. In: E. Wajnberg \& S. A. Hassan (eds.), Biological control with egg parasitoids. Wallingford, $\mathrm{CAB}$ International, pp. 165-200.

SIFONTES, J. L. A., OBREGON, J. R., CUELLAR, S. R. \& GARCÍA, J. L. A., 1988, Hábitos oviposicionales de Spodoptera frugiperda (J. E. Smith) (Lepidoptera: Noctuidae) en plantas de arroz. Rev. Cen. Agríc., 153: 11-15.

SUZUKI, Y., TSUJI, H. \& SASAKAWA, M., 1984, Sex allocation and effects of superparasitism on secondary sex ratios in the gregarious parasitoid, Trichogramma chilonis (Hymenoptera: Trichogrammatidae). Anim. Behav., 32: 478-484.
THOMPSON, M. S. \& STINNER, R. E., 1990, The scale response of Trichogramma (Hymenoptera: Trichogrammatidae): variation among species in host specificity and the effect of conditioning. Entomophaga., 35: 7-1.

TOONDERS, T. J. \& SÁNCHEZ, J. L. C., 1987, Evaluación de la efectividad de Trichogramma spp. (Hyemnoptera: Trichogrammatidae) en el combate de Spodoptera frugiperda (J. E. Smith) (Lepidoptera: Noctuidae) recomendaciones para su uso. Centro de Entomología y Acarología, pp. 75-84.

VINSON, S. B., 1998, The general host selection behavior of parasitoid Hymenoptera and a comparison of initial strategies utilized by larvaphagous and oophagous species. Biol. Cont., 11: 79-96

ZUCCHI, R. A. \& MONTEIRO, R. C., 1997, O gênero Trichogramma na América do Sul, pp. 41-66. In: J. R. P. Parra \& R. A. Zucchi (eds.), Trichogramma e o controle biológico aplicado. FEALQ. Piracicaba, 324p.

ZUCCHI, R. A., PARRA, J. R. P. \& SILVEIRA NETO, S., 1991, Trichogramma species associated with some lepidopterous pests in Brazil. Les Coll. L'INRA, 56: 131-134. 